\title{
RESOLUSI KONFLIK DALAM PERSPEKTIF PSIKOLOGI LINTAS BUDAYA
}

\author{
Retno Kumolohadi dan Sonny Andrianto \\ Universitas Islam Indonesia
}

\begin{abstract}
Abstrak
Tulisan ini bermaksud membahas tentang seluk beluk konflik terutama konflik yang bersifat komunal dengan segala macam latar belakang masalah atau motifnya. Konflik adalah suatu fenomena umum, namun tetap memerlukan resolusi supaya dampak yang merugikan dari konllik tersebut tiolak meluas. Salah satu kajian tentang resolusi konflik dapat dilakukan dengan pendekatan Psikologi Lintas Budaya. Menurut kajian Psikologi Lintas Budaya, dalam meresolusi konflik perlu mempertimbangkan pola-pola yang dipilih untuk setiap budaya. Pola-pola tersebut telah menjadi keblasaan dan susah untuk dihilangkan begitu saja meskipun globalisasi telah merambah ke selunuh penjuru dunia. Adapun pola-pola resolusi konflik itu dapat berupa akomodasi, penghindaran, kompetisj, dan kolaborasi. Khusus berkaitan dengan masyarakat Indonesia yang pluralistik, pemahaman pada tiap budaya sangatlah penting dilakukan sebab terbukti selama ini resolusi konflik sulit dilakukan karena pihakpihak terkait tidak dapat menjawab kepentingan atau mengubah persepsi dari kalompok yang berkonflik.
\end{abstract}

Kata-kata Kunci: Resolusi Konflik, Psikologi, Lintas Budaya, Indonesia

\section{PENDAHULUAN}

$\mathbf{M}$ asyarakat dunia mendambakan hidup secara rukun dan damai sehingga dibuatlah suatu sistem yang mengaturtata kehidupan dalam kelompok-kelompok masyarakat. Sistem tersebut berupa aturanaturan khusus, hukum, dan norma-norma yang bersumberdari konsep-konsep pikiran sebagian besarwarga masyarakat mengenai hal-hal yang dianggap memilkki nilai tinggi (Koentiaraningrat, 1987). Bag yang melanggar sistem pada umumnya mendapat sanksi sosial, sebaliknya yang mematuhi sistem tersebut mendapatkan pengakuan sebagai anggota kelompok, mendapatkan penghargaan, dan tempat yang baik di kalangan masyarakat.
Konsekuensi kepatuhan dan ketidakpatuhan terhadap sistem tata kehldupan tersebut membuat masyarakat berupaya untuk menyesuaikan diri dengan cara bersikap dan berperilaku sejalan dengan sistem yang berlaku. Menurut Triandis (1996) beberapa sikap dan perilaku yang penting daiam lingkup sosial kemasyarakatan ada|ah resolus| konflik, jarak sos|a|, perilaku menolong, dominasl, keriasama, kepatuhan, dan keterbukaan. Sikap dan perilaku tersebut dimungkinkan terjadi pergeseran dari masa ke masa.

Masa sekarang dikenal sebagai era globalisasi. Isu paling populer of era globalisasl yang tengah berlangsung sekarang 
ini adalah upaya untuk menguburkan perbedaan. Kenyataan justru berkebalikan bahwa etnik, agama, dan ras tetap berpengaruh kuat di hampir setiap kehidupan, bahkan kelompok kepentingan etnik agama dan ras semakin vokal bersuara. Semakin vokal suatu etnik, agama atau ras akan menimbulkan kecemburuan dan persaingan, bahkan dapat berakhir dengan konflik yang tak kenal ujung pangkalnya. Contoh konflik yang hingga saat ini belum tuntas adalah antara Israel vs Palestina, di Indonesia GAM (Gerakan Aceh Merdeka) vs TNI serta konflik yang berkembang di Maluku dan Poso. Adapun latar belakang konflik pun beragam, mulai dari perebutan wilayah atau tanah garapan, konflik antar agama, konflik antar suku atau etnis, serta konflik bermotif dendarn.

\section{DIMENSI DAN DAMPAK KONFLIK}

Konflik mewamai kehidupan manusia sepanjang hayatnya, mulai dari konflik yang dialami sehari-hari sampai konflik yang lebih besar. Dennen dan Falger (1990) menyebut konflik sebagai pertentangan dalam hal kepentingan, tujuan, nilai-nilai, kebutuhankebutuhan, harapan-harapan dan atau ideologi.

Freeman (Dennen dan Felger, 1990) membagi dimensi konflik menjadi dua, yaltu fractionating conflict dan cross-cutting conflict. Fractionating conflict terjadi ketika kelompok-kelompok yang bersengketa terpecah menjadi bagian-bagian oleh karena adanya berbagai perbedaan yaltu dalam bidang: ekonomi, politik, pendidikan, agama, etnls, rasial. Kekerasan bahkan diperbolehkan oleh kelompok-kelompok untuk melindungi diri melawan ancaman yang ekstrim yang ditunjukkan oleh pihak lain.

Cross-cutting conflict terjadi ketika pihak-pihak yang bersengketa berada dalam kondisi oposisi yang parah tetapi pihak- pihak itu sedang bersekutu. Dua pihak beropos|si ini bersekutu disebabkan karena sedang sama-sama menghadapi konflik lain yang mengancam keduanya. Jadi pada konflik ini masih dimungkinkan adanya negosiasi dan kompromi.

Konflik-konflik yang besar salah satunya adalah konflik komunal. Konflik komunal dapat mengancam integrasi negara-bangsa mela|ui dua kecenderungan gerak dinarnika konflik: gerak keluar atau sentripetal dan ke dalam atau sentrifugal. Gerak sentripetal terjadi ketika konflik di suatu daerah tertentu meluas ke daerah-daerah lan karena daerahdaerah itu memiliki karakter sosial yang relatifi sama Gerak konflik semacam ini bukan sesuatu yang sulit terịadi karena sarana komunikasi, persebaran informasi, mobilitas sosial dan adanya provokator yang memungkinkan konflik menyebar meluas dengan cepat. Gerak sentrifugal teriadi ketika konflik di daerah tertentu terus menerus berlangsung hingga mencapai tingkat konflik demikian mendalam, menimbulkan kerusakan yang parah dan menghancurkan struktur masyarakat yang berada pada tingkat paling rendah

Konflik dapat berakibat adanya keinginan untuk mencederai secara fisik. Kekerasan digunakan sebagai satu cara penyelesaian biasanya karena tidak ada lagi jalan tengah yang dapat ditempun oleh pihak-pihak yang berkonfilik. Pada tindak kekerasan, pelaku biasanya telah kehilangan kontrol diri. Pihak yang terkena kerugian akibat konflik dapat kehilangan kesabarannya sehingga timbullah amarah dan balas dendam. Bila terjadi pada sekelompok orang terjadilah kerusuhan..

\section{SUMBER KDNFLIK}

Brigham (1991) mengungkapkan bahwa konflik bersumber dari (1) context of the current interaction (kondisi hubungan yang 
terjadi saat ini), (2) historyof prior interactions (kondisi hubunganyang terjadi pada masa lalu), (3) personality and needs (kepribaian dan kepentingan), serta (4) perception and misperceptions of the other side (persepsi dan mispersepsi terhadap kelompok tain).

Kondisi yang semula aman dan damai, seketika dapat berubah menjadi situasi konflik yang berkepanjangan. Layaknya sebuah bahaya laten, konflik yang lama terpendam suatu saat dapat muncul ke permukaan dalam bentuk malapetaka daiam kehidupan kemasyarakatan. Perbedaan kepribadian dan kepentingan yang tidak dipahami secara dewasa, seringkali dapat memunculkan persepsi yang berbeda serta kesaiahan daiam memberikan penafsiran terhadap suatu situasi.

Atmosiswoyo (2000) mengungkapkan bahwa konfiik yang terjadi di belahan dunia manapun pada dasamya disebabkan karena berbagai hal, yaitu: adanya rasa superionitas, kecurigaan, persaingan yang tidak sehat, polarisasi, ketakutan akan masa depan.

Rasa superioritas dari satu etnis dan merasa kelompoknya saja yang paling sempurna dan menganggap kelompok lain lebih rendah juga merupakan perricu konflik. Ras Jerman pada jaman Hitler berkuasa menganggap diri mereka keturunan Aria, yaitu etnis tepilih yang paling sempuma. Saat itu yang jadi sasaran adalah dari etnis Yahudi. Etnis Yahud dahuiu diburu, dibantai habis dalam barak-barak tahanan.

Myers daiam Atmosiswoyo (2000) menyebutkan adanya sumber-sumber kecurigaan yang menjadi sajah satu penyebab konfilik, yaitu: (a) Sumber-sumber prejudis masyarakat yaitu masaiah ketidaksamaan kedudukan dalam masyarakat, adanya diskriminasi, periakuan tidak sama antara ingroupnya dengan outgroupnya. Contoh nyata adalah fasilitas yang serba modern bagi mereka yang tinggai di freeport irian Jaya, sedangkan bagi penduduk setempat fasilitasnya sangat menyedihkan. (b) Sumber-sumber emosional dari syak wasangka yaitu frustasi dan agresi. Frustasi dapat menjadi potensi besar adanya agresi Frustasi yaitu gangguan terhadap tercapainya suatu tujuan atau keinginan dapat memicu agresi karena menimbulkan perasaan menyakitkan. Kebutuhan akan kedudukan membuat orang menghalalkan segala cara. Yang ditindas tidak terima sehingga mereka sering dibuat frustasi. Agresi yang bersifat individual bisa meningkat menjadi agresi massal. Kerusuhan ini biasanya disebabkab oleh rasa frustasi sosiai yang diaiami oieh sekelompok masyarakat. Misainya masyarakat yang berada dalam tekanan poittiik sekian lama tidak akan kuat menahan beban dan meletus daiam bentuk tindakan anarkis. (c) Sumber-sumber kognitif dari prasangka yaitu adanya kategorisasi atau pengeiompokan. Namun hai ini dapat berdampak bagi perasaan anggota kelompok yang merasa bahwa dininya mirip dengan kelompoknya dan berbeda dengan kelompok lain (outgroup homogeneity $e$ fect. Ada kecenderungan orang lebih suka pada orang yang lebih mirip daripada yang berbeda (ingroup bias), (d) Perhatian pada perbedaan stimuli dan perbedaan orang yang dapat dirinci menjadi persaingan, rasa ketidakadilan, mispersepsi serta kurangnya komunikasi.

Persaingan yang tidak sehat antar etnis d perantauan juga salah satu penyobab konflik Persaingan ini terjadi karena adanya kekhawatiran tidak mendapat bagian dari porsi yang selama ini dinikmati bersama. Persaingan semakin memanas manakaia keiompok pendatang iebih bethasii daripada kelornpok pribumi.

Polarisasi merupakan penyebab konflik yang umum terjadi di daerah perkotaan. Birokrat biasanya penduduk pribumi asli, sedangkan etnis iain hanya sedikit 
mendapat kesempatan. Suatu etnis berkuasa d bidang ekonomi sedang yang lain hanya jadi petani biasa. Hal ini tentu akan menimbulkan kesenjangan yang tinggi. Salu etnis akan terlihat lebih dominan dibandingkan dengan etnis lain. Konflik akan terjadi dan sangat mungkin akan berakhir dengan kekerasan atau perilaku agresi.

\section{POLA RESOLUSI KONFLIK}

Konflik tidak hanya dapat diselesaikan dengan pendekatan politik dan ekonomi tetapi juga pembenahan dalam proses psiko-kultural, karena konflik seringkali terbentuk akibat kepercayaan sosial. Psikologi mempunyai peran besar dalam penyelesaian konflik karena mampu membantu mengatasi kepercayaan sosial dalam bentuk stereotip atau prasangka yang ekstrim, kaku, dan terpolarisasi (Kisbiyah, 2000).

Bagaimana pola manusia menyelesaikan konflik dari budaya yang berbeda, dipandarng dari sudut pandang Psikologi Lintas Budaya? Menurut kajian lintas budaya, konflik dapat terpecahkan dengan melihat dimensi individualisme kolektivisme baik dalam ingroup maupun oulgroup. Konflik sering menjadi sangat sulit untuk diselesaikan karena individu-individu yang berkonflik memiliko nilai-nilai yang berbeda dan menyukai pola resolusi konflik yang berbeda pula.

Terdapat sejumlah penelitian empiris yang mengungkap bagaimana dan mengapa perbedaan kultural mempengaruhi pilihanpilihan orang terhadap pola-pola penyelesaian konflik. Salah salu penelitian tersebut adalah penelitian Garbrielidis, dkk. (1997) yang mencoba membandingkan pola-pola resolusi konfik antara bangsa dengan budaya individualistik yang diwakili oleh Amerika dan bangsa dengan budaya kolektivistik yang diwakili oleh Mexico dengan menggunakan model dual-concem.
Menurut model dual concem, pola-pola pribadi dari resolusi konflik ditentukan oleh perhatian individu kepada hasil tindakan mereka sendiri dan perhatian mereka terhadap hasil tindakan orang lain. Dua dimensi dari model dual-concern yang dikombinasikan akan menghasilkan empat pola dasar dari resolusi konflik, yaitu: akomodasi, penghindaran, kompetisi, dan kolaborasi.

Akomodasi adalah suatu pola resolusi konflik yang pusat perhatiannya lebih tinggi ke orang lain daripada ke diri sendiri. Pola resolusi konflik ini melibatkan pengorbanan tujuan-tujuan sendiri untuk memuaskan keinginan orang lain atau mengalah atas dasar kesadaran.

Penghindaran adalah suatu pola resolusi konflik yang pusat perhatiannya ke orang lain dan diri sendiri sama-sama rendah. Individu membiarkan konflik berlalu tanpa ada penyelesaian atau mengijinkan orang lain untuk mengambil tanggung jawab untuk memecahkan masalah.

Kompetisi adalah suatu pola resolusi konflik yang tinggi penatiannya ke diri sendiri tetapi rendah ke orang lain. Pada kompetisi orang berusaha untuk memaksimalkan hasil tindakannya. Konflik dipandang sebagai suatu proposisi menang atau kalah.

Kolaborasi adalah pola menang-menang yang pusat perhatiannya antara diri dan orang lain sama-sama tinggi. Individu yang berorientasi pada kolaborasi akan mencoba mengintegrasikan keinginan-keinginan dari kedua belah pihak untuk mendapatkan suatu penyelesaian.

Hofstede dkk. dalam Garbrielidis, dkk. (1997) mengemukakan bahwa pada budaya individualistik orang-orang memandang diri sebagai kesaluan diri yang unik terpisah dari orang lain Budaya individualistik menanamkan nilai-nilai yang bermanfaat untuk menaikkan keinginan-keinginan individu dan memisahkan individu dari kelompok (Triandis, dkk. dalam Garbrielidis,dkk. 
1997). Sebaliknya pada budaya kolektivistik memandang hasil tindakannya terkait erat dengan hasil tindakan orang lain

Orang pada budaya kolektivistik, men:punyai kecenderungan untuk memillh strategl 'harmoni' dari resolusi konflik, sedangkan orang pada budaya individualistik memilih strategl yang lebih kompetitif (Bamlund, dkk. dalam Garbrielidis, dkk.1997). Pada budaya Asia atau budaya kolektivis perasaan harmoni berharga tinggl dan kebahagiaan orang lain dirasa lebih penting daripada kenyamanan dirinya sendiri. Bamlund berargumentasi bahwa orang Jepang menangani konflik melalui penghindaran atau akomodasi serta kolaborasi walau tidak cukup sering, karena kolaborasi sering menampakkan ekspresi cara pandang yang berbeda.

Penelitian Garbrielidis, dkk. (1997) ini dapat menggambarkan adanya perbedaen dalam penilihan pola resolusi konflik antara masyarakat individualistik dan kolektivistik. Partisipan adalah mahasiswa dari Amerika Barat Daya yang mewakili masyarakat individualistik berjumlah 103 dan dari Mexico yang mewakili masyarakat kolektivistik ber jumlah 91 orang.

Peneliti berargumentasi bahwa orang Mexico bejuang untuk menciptakan hamoni sebisa mungkin. Hasilnya menunjukkan bahwa bangsa Mexico lebih tinggi secara signifikan skornya pada akomodasi dan kolaborasi daripada bangsa Amerika. Hasil ini mendukung riset sebelumnya yang menunjukkan bahwa pada budaya kolektivistik, suka menyelesaikan konflik dengan kemungkinan rasa permusuhan paling sedikit (Leung dkk. dalam Garbrielidis, dkk, 1997) dan pada cara-cara yang membuat dirinya tidak memalukan (Ting-Toomey dalam Garbrielidis, dkk, 1997). Orang Mexico ternyata terpengaruh oleh sebagian sifat orang individualis Amerika sehingga bangsa ini tidak lepas dari gaya kompetitif, terutama pada para eksekutif muda. Keramahtamah- an, suasana bebas konflik dan konfrontasi telah melekat pada diri mereka.

Bangsa Mexico berkompetisi dengan memanipulasi hubungan, pembentukan aliansi atau menyenangkan dii dengan cara dekat dengan orang yang mempunyai kekuasaan. Jadi pada situasi bisnis, bangsa Mexico sebenamya secara personal berkompetisi tetapi biasanya tidak secara terbuka. Kompetisi ini terjadi karena bangsa Mexico adalah unik, seperti nilai individualistiknya bangsa Amerika. Meski demikian soal prestasi jug a diperhatian oleh bangsa Mexico. Sedangkan pada gaya-gaya yang rendah perhatiannya pada orang lain, penghindaran lebih disukal daripada kompetisi. Pengingkaran digunakan sebagal teknik pemeliharaan hubungan interpersonal sebab dapat mengurangi kemungkinan konflik tebuka. Hal ini tidak berlaku untuk aktivitas negosiasi bisnis

Kolaborasi yang dipilih oleh bangsa Mexico ternyata juga dipilih oleh orang Brazilia. Sedangkan orang Jepang justru tidak menyukai kolaborasi (Bamlund, dalam Garbrielidis, dkk, 1997) karena menurut mereka justru mengganggu hammoni akibat terlalu terbukanya ekspresi jika terjadi pandangan yang bertolak belakang. Kolektivis Asia yang diwakili Jepang dan Amerika latin yang diwakili Mexico, sama dalam hal kesukaannya untuk menyelesaikan konflik dengan pola pengingkaran dan akomodasi, dengan kompetisi sebagal jalan terakhir.

Resolusi konflik yang penting dilakukan menurut Mar'lyah (2000) adalah dengan pendekatan kepentingan. Pendekatan ini bisa dikembangkan dengan membangun dan memperkuat masyarakat sipil. Prinsipnya adalah dengan cara dialog tanpa kekerasan. Dialog dapat dilakukan pada tingkat first track diplomacy yang resmi dengan dibentuk komite-komite maupun second track diplomacydengan dialog yang 
dilakukan oleh masyarakat. Pendekatan ini memerlukan proses yang panjang, namun layak untuk dilkuti. Adapun tahap-tahap pelaksanaan dari pendekatan kepentingan adalah sebagai berikut:

1. Mengidentifikasi pihak-pihak terkait yang sedang berkonflik

2. Mengidentifikasi kesamaan visi dan tujuan pentingnya resolusi konflik

3. Mengidentifikasi isu-isu yang ada, mendengarkan sejarah masa lalu yang kelam (misalnya: terbunuhnya keluarga, korban penculikan, kekerasan, perkosaan, dan sebagainya.)

4. Mengeksploitasi nilai-nilai, kebutuhan, dan kepentingan yang ada

5. Menganalisa dan mensintesakan

6. Mencari solusi kreatlf yang menguntungkan bagi kedua belah pihak

7. Mencari persetujuan dari pihak yang saling berkonflik

8. Melakukan action plan, dengan membuat kebijakan-kebijakan.

\section{RESOLUSI KONFLIK DI INDONESIA, POLA APA YANG DIPILIH?}

Telah diketahul bersama bahwa masyarakat Indonesia terdiri dari banyak kelompok etnik dengan karakteristik yang amat beragam, sehingga sulit dicari sebagai cir khas masyarakat Indonesia yang benarbenar mewakili populasi. Sesuai dengan falsafah Bhinneka Tunggal lka, maka Indonesia dapat digolongkan ke dalam masyarakat plural dengan kebudayaan majemuk. Masyarakat berkebudayaan majemuk adalah masyarakat yang memiliki banyak tradisi budaya, plurallsme dihargai sehingga kekhasan masing-masing budaya tetap dipertahankan.

Masyarakat plurallstik muncul sebagai akibat dari berbagai kejadian sejarah seperti kolonisasi, pembentukan negara dan Migrasi (John,dkk, 1995). Masyarakat Indonesia adalah masyarakat yang pluralistik dengan kemungkinan konflik yang tinggi, terutama konflik horisontal. Pluralitas ini adalah konsekuensi dari banyaknya suku bangsa yang berdom|sili di kawasan Indonesia dengan ibuan pulau-pulaunya. Bentuk negara kepulauan dengan pemisahan batas wilayah adalah laut diakui atau tidak ternyata cukup menyulitkan untuk dapat melakukan koordinasi dan hal ini dapat menjadi ancaman bagi kesatuan negara Indonesia.

Hubungan di antara kelompok-kelompok budaya yang berbeda dalam suatu masyarakat yang plural dapat dijelaskan dalam berbagai alternatif, yaitu: asimllasl, integrasi, separasi dan marjinalisasi. Apablla asimilasi dan separasi terjadi secara menyeluruh maka masyarakat tersebut tidak lagi plural.

Budaya yang nyarls sama di suatu bangsa dalam kasus asimilasi akan muncul ke permukaan menjadi budaya yang menonjol sedangkan dalam kasus separasi masyarakat plural tersebut akan pecah menjadi beberapa masyarakat yang lebih kecil Independen dan mungkin lebih homogen.

Marjinalisasi dan segregasi suatu masyarakat pada prinsipnya masyarakat thu tetap pluralistik, namun prakteknya hanya sedikit Interaksi dan partisipasi antara kelompok-kelompok. Di lain pihak, Integrasi merupakan situasi di dalam masyarakat yang telap, dan kelompok-kelornpok di dalamnya tetap mempertahankan kekhasan mereka dan pada saat yang sama berpartisipasi bersama di dalam berbagai institusl besar di dalam kelompok besaryaitu negara.

Perbedaan etnik, agama, ras dijadlkan justifikasi dan legitimasi atas konflik horisontal yang terjadi, padaha! faktor utamanya bukan seperti itu misalnya karena ketidakadilan, politik, ekonomi, hukum, dan lainlain. Terlalu naif bila pluralisme etnik di 
Indonesia merupakan penyebab tunggal terjadinya konflik. Bila bentuk-bentuk ini terus berlangsung, maka dimungkinkan akan menjadi trand dan model dl masa mendatang. $\mathrm{Hal}$ ini dimungkinkan karenapenyebab konflik sulit terungkap dan terpecahkan serta kurangnya kepastian hukum.

Setiap konflik dapat berakhir dengan pembunuhan atau kekerasan massal. Kekerasan massal pada umumnya bersifat leblh Irrasional, lebih garang, lebih meluapluap emosi permusuhannya. Pada saat indlvidu berada pada situasi massa, tanggung jawab dibagi secara merata kepada tiap individu. Massa merasa anonim dalam kelompok itu dan merasa dapa membunuh tetapi terbebas dari konsekuensikonsekuensinya. Individu kehilangan jati dirinya dan lebur dalam kelompok massa tersebut dan ini yang disebut sebagai deindividuasi

Konflik di Indonesia pada dasarnya memiliki karakter yang mirip antara satu dengan yang lain. Kelompok-kelompok yang berkonflik tersebut berdekatan secara fisik dan pada umumnya mengalami bentukbentuk kekerasan dan trauma. Bangsa Indonesia dalam berbagai kasus konfllik d tan ah air dengan motif etnis, agama dan ras misalnya, kini sedang berupaya keras untuk melakukan resolusi konflik dengan berbagai cara.

Bangsa Indonesia sebagai bangsa yang masyarakatnya plural, besar kemungkinan memiliki pilihan pola resolusi konfik tertentu untuk masing-masing kelompok. Pola apa yang dipitih untuk menyelesaikan konflik? Dapatkah ditarik satu kesamaan pola resolusi konflik dari berbagai budaya yang ada di Indonesia? Menilik karakteristik yang dimiliki bangsa Indonesia, maka sanga! mungkin polanya hampir mirip dengan orang Asia pada umumnya. Bangsa Indonesia sesungguhnya adalah bangsa yang masih menjunjung tinggi harmoni, suka me- nyelesaikan konflik dengan kemungkinan rasa permusuhan paling sedikit dan pada cara-cara yang membua! dininya tidak memalukan. Lalu mengapa konflik tak kunjung bisa diselesaikan dengan tuntas? Pertanyaan besar tersebut barangkali lebih mudah dijawab apabila para pihak yang berkepentingan telah memahami pola-pola yang dipilih untuk kelompok masyaraka! d Indonesia yang memilliki nilai-nilal budaya tersendiri.

Beberapa pola resolusi konflik pada suku-suku di Indonesia dapat dicontohkan sebagai berikut: Pola pengingkaran digunakan oleh beberapa suku primitif d Irian Jaya ketika berkonflik. Masalah dibiarkan berlalu, namun sebagai gantinya kedua pihak yang berkonflik tersebut melakukan upacara pembakaran "babi guling" sebagai simbol perdamaian.

Masyarakat desa Sasak di Lombok menggunakan "begundem" atau "betanding reraosan" yaitu beradu pendapat untuk mencari kebulatan pendapat bagi resolusi suatu konflik. Kendati lembaga begundem ini sudah banyak mengalami pergeseran namun d beberapa tempat masih tetap dipertahankan kelestariannya. Kebulatan pendapat dalam "begundem" tidak sematamata diputuskan oleh satu pihak tetapi oleh beberapa pihak yaitu: kepala desa dan pembantu-pembantunya, krama desa atau suatu dewan yang terdiri dari orang-orang yang: terhormat dan berwibawa serta ahli dalam adat, serta petugas-petugas agama dan petugas-petugas alam ghab atau dalam hal ini adalah para kyai, penghulu dan para mangku. Hasil dari "begundem" adalah diterimanya secara baik pertimbanganpertimbangan dari para pihak tersebut di atas oleh kelompok yang bersengketa. Caracara yang digunakan dalam "begundem" tersebut membentuk pola kolaborasi dalam meresolusi suatu konflik. Keputusan akan diumumkan kepada pihak yang ber- 
sangkutan dan kepada masyarakat kemudian ha ini dilaksanakan. Krama desa bertugas untuk mengawasi pelaksanakan keputusan "begundem". Apabila keputusan dari lembaga "begundem" tersebut tidak dilaksanakan oleh pihak-pihak yang bersengketa dalam artian pinak-pihak tersebut mengambil sikap yang bertentangan, maka sanksi adat yang berat akan dijatuhkan (Koesnoe, 1979)

Di kalangan masyarakat Jawa (Jawa Tengah dan Jawa Timur) pada umumnya, jika ada kelompok-kelompok yang bersengketa maka kelompok tersebut dipertemukan dalam sebuah forum musyawarah dan mufakat. Forum ini kalau di Desa dipimpin oleh seorang Kepala Desa sebagai juru damainya. Orang Jawa menganut asas rukun, patut, selaras, tertib, damai dan adil, sehingga diharapkan setiap sikap dan perilaku orang jawa mengarah kepada pengertian dan penerimaan, memaafkan kesalahan dan kekurangan orang lain, menjauhkan diri dari percekcokan dan perselisihan, menjauhi untuk menyinggung perasaan sesama (Syamsudin, 1997). Akibatnya orang Jawa cenderung menjauhi konflik yang bersifat teruka, bahkan akan memilih pola akomodasi yaitu berkorban untuk orang lain daripada diri sendiri danggap kurang bisa bertoleransi dan menjaga nila:nilai.

Berdasarkan contoh d atas jelas bahwa suatu resolusi konflik tak semudah membalik tangan apalagi dengan memaksakan suatu pola tertentu yang sebenarnya kurang mengakar pada adat masing-masing daerah.

\section{PENUTUP}

Konflik merupakan sebuah fenomena yang umum dalam pergaulan masyarakat, namun dapat menimbulkan dampak yang mengikan. Konflik dapat merupakan konflik potensial maupun konfik yang bersifat terbuka. Keduanya sama-sama bebahaya sehingga penting dipkikirkan resolusinya.

Resolusi konflik pertu mempertimbangkan asal budaya, oleh karena itu memaknai budaya dengan perspektif Psikologi Lintas Budaya penting dilakukan. Selama ini resolusi konflik sulit dilakukan karena pihakpihak terkait tidak dapat menjawab kepentingan atau mengubah persepsi dari kelompok yang berkonflik tersebut dan hal itu disebabkan karena kurangnya pernahaman tentang pola-pola yang dipilih sebagai resolusi konflik

Bangsa Indonesia adalah bangsa yang plural, besar kemungkinan memiliki polapola resolusi konflik yang berlainan pula. Namun demikian bangsa Indonesia sesungguhnya adalah bangsa yang masih menjunjung tinggi harmoni yaitu cenderung suka menyelesaikan konflik dengan kemungkinan rasa permusuhan paling sedikit dan pada cara-cara yang membuat dirinya tidak memalukan. Apabila pihakpihak terkait dapat memahami pola-pola resolusi konflik dabm suatu budaya tertentu, maka perwujudan perdamaian adalah satu keniscayaan. a

\section{DAFTAR PUSTAKA}

Atmosiswoyo, S, 2000. Acuan yang Sifatnya Lintas Budaya untuk mencari Alternatif Mengatasi Konflik Etnis. Jumal Psikologi Sosial: No Vl/th VIII/ Maret 2000. Jakarta: Bagian Psikologi Sosial Fakultas Psikologi Universitas Indonesia.

Brigham, J.C. 1991. Social Psychology 2nd' edition New York: HarperColins Publishers Inc.

Dennen, V.D., Falger, V. 1990. Sociobiology and Conflict. London: Chapman and Hall. 
John, B.W. Poortinga, Y.P.O.H., Segall, M.H., Dasen, PR. 1999. Psikologilintas Buda ya Risetdan Aplikasi (Terjemahan). Jakarta: Gramedia.

Garbrielidis C., Ybanra O, Pearson V.M.D.S., Villareal L. 1999. Prefered Styles of Conflict Resolution: Mexico and the United States. Joumal of Cross Cultural Psychology. Volume 28 No 6 .November 1997. 661-677. Sage Periodicals Press.

Kisbiyah, Y. 2000. Agresi dalam Tinjauan Psikologi. Bunga Rampai. Melawan Kekerasan Tanpa Kekerasan Yogyakarta Pustaka Pelajar.
Koentjaraningrat. 1987. KebudayaanMentalitas dan Pembangunan. Jakarta: PT Gramedia.

Koesnoe, M. 1979. Catatan-catatan terhadap Hekum Ada Dewasa hi. Sunbaya: Airlangga University Press.

Mar'iyah C. 2000. Memahami Konflik dan Pengelolaan Konflik Secara Konstruktif. Jumal Transformasi. April 2000.

Suseno, F.M. 2000. Bunga Rampai. Melawan Kekerasan Tanpa Kekerasan. Yogyakarta: Pustaka Pelajar.

Syamsudin, M. 1997. Kepala Desa sebagai Hakim Perdamaian Desa. Arena Almamater. No. 42 Tahun XII. Januari-Maret 1997. Halaman 15-29. 